Helen Makogon, Volodymyr Chalapko, Serhiy Guba, Vladyslav Starychenko, Viktor Moskalenko, Yuriy Krasnoshapka

Military Institute of Tank Troops of National Technical University, Kharkiv, Ukraine

\title{
USING OF THE MATHEMATICAL APPARATUS REGRESSION ANALYSIS TO UNIFY THE CALCULATING METHODOLOGY FOR THE T-64B TANK'S OVERHAUL LIFE
}

\begin{abstract}
The subject matter of the article is the life cycle of a T-64B tank sample during the period from normal operation in a combat training group to resource consumption and carrying out average and capital repairs. The goal of the study is to develop a model of dependence of inter-repair service life of the T-64B tank sample on the machine operating conditions and, on its basis, a methodology for controlling the parameters of individual assemblies and systems of the tank sample during its life cycle. The tasks to be solved are: to analyze the results of statistical records of tank system failures and damages number and identify the predicates set affect the inter-repair service life of the machine depending on conditions of its tasks for the intended purposes; to create the regression equation for getting the unified analytical dependence of inter-repair service life of the T-64B tank sample in the period from normal operation in training and combat group to service life and overhaul; to investigate specific influence of reliability indices on the machine's service life. General scientific and special methods of scientific knowledge are used. The method of hierarchy analysis, mathematical apparatus of probability theory and multidimensional statistical analysis were used. The following results are obtained. A set of predicates influence the inter-repair service life of the machine depending on conditions of its tasks for the intended purposes fulfillment has been determined. A regression equation has been drawn up to obtain a unified analytical dependence of the overhaul life of a T-64B tank sample during the period from normal operation in a combat training group to the development of a resource and carrying out of intermediate and complete overhauls were drawn up. Engineering solutions have been proposed to implement a methodology for monitoring the parameters of individual units and systems of the tank sample during its life cycle, namely integrated real-time monitoring of oil condition and recording of engine operating hours under various load conditions. Conclusions. The space of features characterizes the conditions of the tank sample tasks for its intended purposes, includes service life, crew training, operation, seasonality of the unit's performed tasks nature, machine operating time since the last service and range of the vehicle before the next overhaul. The analytical relationship between the individual factors determining the conditions under which the T-64B tank sample performs its tasks for the intended purposes and the machine's service life consumption as a dependent variable can be determined in the form of a regression equation. Differentiated control of the parameters of individual assembly units and systems of the tank sample plays a leading role in ensuring the combat readiness and efficiency of the use of aging samples of weapons, insures personnel against possible accidents and catastrophes, sudden failures.
\end{abstract}

Keywords: service life of the T-64B tank sample; operating conditions; regression analysis; differentiated control of parameters.

\section{Introduction}

Formulation of the problem and research tasks. The T-64 tank and its modifications remain one of the most common and recognizable symbols of modern warfare. Created in the early 1960s, it was very advanced for its time and has retained the ability to be upgraded to this day.

Restoration, repair and upgrading of existing armored weapons and military equipment (AWME) vehicles is one of the constant factors that ensure the high combat readiness of a unit. However, during the life cycle individual units and systems of the sample tank have different impact on the life between overhauls, thus contributing to irrational use of the latter.

Taking into account individual properties of a particular vehicle, its operating conditions, character of loading schedule and other factors, the rate of wear of both separate units and subsystems of the vehicle can significantly differ from the values determined for the analogue sample. In this regard, the task of finding ways to unify the method of calculating the service life of the T-64B tank, depending on the conditions of performing its tasks for the intended purposes seems to be relevant.

Analysis of recent research and publications on the above issues shows the relevance of the study.
In general, warranty and overhaul resources of AWME are defined by guiding documents, but the method of their calculation, normative indicators are obsolete, unique for samples of equipment for different purposes, despite the differences in the mechanisms of consumption of overhaul resources of individual components.

The authors present a reasoned critique of the lack of differentiated indicators of overhaul mileage in the system of maintenance and repair of AMWE, but ways to develop technically sound standards for overhaul mileage and, accordingly, maintenance of AMWE samples are not fully explored [1-5].

The authors are of the opinion that a more thorough study of the feasibility of full maintenance under real operating conditions is required, as well as the scope of daily and numbered maintenance work, based on the time and scope of the tasks that the sample AWME performs.

The goal of the study is to develop a model of dependence of inter-repair service life of the T-64B tank sample on the machine operating conditions and, on its basis, a methodology for controlling the parameters of individual assemblies and systems of the tank sample during its life cycle.

To achieve this goal the following research tasks are solved: 
- to analyze the results of statistical records of tank system failures and damages number and identify the predicates set affect the inter-repair service life of the machine depending on conditions of its tasks for the intended purposes;

- to create the regression equation for getting the unified analytical dependence of inter-repair service life of the T-64B tank sample in the period from normal operation in training and combat group to service life and overhaul;

- to investigate specific influence of reliability indices on the machine's service life.

\section{Main material}

1.1 The results of statistical accounting of the number of failures and damage to tank systems in the period from normal operation to aging and overhaul. The tank is a complex technical system. During its operation, various types of failures may occur. The availability of data on machine failures provides opportunities to systematize, establish the causes and develop measures to eliminate and develop methods for predicting reliability, optimize the timing and amount of numbered maintenance and increase the time of repair resources. The classification of failures, adopted in the scientific literature on the theory of reliability, is quite relative.

So, to obtain the dependence on the generalized assessment of the existing level of reliability of machines, its constituent units and components, it is necessary to consider the division of machine failures into operational and resource.

It is believed that operational failures occur due to accidental causes, which are due to a combination of adverse factors arising from the operation of products with low properties, which are inherent in the design, and more often in the manufacture of machines.

The reasons for operational failures are various minor violations of the established rules, norms of design, production, storage and repair of machines, their operation.

These are failures that are not usually expected. Operational failures characterize faultlessness.

It is believed that in contrast to operational, resource failures occur as expected events associated with natural changes (usually over a long period of time), which take place in the main (base) components of the machine and lead to their extreme condition, extreme wear, breakdowns parts and assemblies due to the reduction of their strength.

When the failed element is restored, the initial (or overhaul) resource of the main nodes is restored.

Resource failures characterize durability.

It should be noted that the operating conditions of the machines are random and have probabilistic characteristics, and failures of units and components of the machine can occur both under normal (failures can be expected in different units of the machine) and under extreme operating conditions.

Given that both "operational" and "resource" failures occur during the operation of machines, and the failure itself is sudden only because its development is too fast over time and hidden for observation, proposed resource and operational failures [6].

1.2 Failures after removal of equipment from long-term storage. Most of the existing weapons of the Armed Forces of Ukraine have been in operation for over 30 years and have been in long-term storage, which inevitably affects its technical condition and combat readiness.

Experience with the use of military equipment has shown that a significant proportion of failures of military equipment is associated with violations of the requirements for its operation by crews, non-compliance with the rules of storage of military equipment for longterm storage, untimely and incomplete implementation of the list and scope of at the time of removal of military equipment from long-term storage.

When military equipment was brought to combat condition to perform combat missions as intended, a significant part of it required maintenance and repair, and in some cases - routine works to renew the service life of military equipment, whereby the indicators of serviceability were not confirmed.

The available statistical data revealed the main (type) failures (malfunctions) at the time of withdrawal of the equipment from long-term storage (Table 1).

\section{Table 1 - The main failures of the T-64B after} removal from long-term storage

\begin{tabular}{|c|c|c|}
\hline № & Name of the T-64B tank sample systems & Failures, \% \\
\hline 1. & Fire control systems & 8 \\
\hline 2. & Weapons & 13 \\
\hline 3. & Power plant & 36 \\
\hline 4. & Electrical equipment & 12 \\
\hline 5. & Undercarriage & 12 \\
\hline 6. & Transmission & 16 \\
\hline 7. & Others & 3 \\
\hline
\end{tabular}

As a result, the current technical condition of the Armed Forces, military equipment in long-term storage (including storage bases) gives a high failure rate, after its commissioning, due to violation of storage requirements and bringing to combat readiness. In particular, storage of engines involves turning the shafts, which is not always done on time and properly [7-9].

1.3 Operation failures. Armored vehicles operational failures are largely due to the fault of the crew and repair units personnel, which make mistakes during operation or during maintenance and repair of the machine. A study of the quantitative analysis of the operational failures flow was conducted on the results of ones operation during performing intended tasks.

Data on the operation of 87 different "ages" machines in the range from normal operation to aging during 2014-2020 were subject to statistical processing, so the sample can be considered sufficient and representative. Generalized quantitative indicators of the flow of operational failures of the sample tank T-64B for a certain period of time are given in Table 2 . 
Table 2 - Quantitative analysis of the operational failures flow for the sample tank T-64B

\begin{tabular}{|c|c|c|c|c|c|}
\hline $\begin{array}{c}\text { Operating time, thousand, } \\
\mathrm{km}\end{array}$ & $\begin{array}{c}\text { Average number of operational failures, } \\
\mathrm{pcs}\end{array}$ & $\begin{array}{c}\text { Intensity, } \lambda_{\mathrm{e}} \times 10^{3}, \\
1 / \mathrm{km}\end{array}$ & $\begin{array}{c}\sigma_{\lambda \mathrm{e}} \times 10^{3}, \\
1 / \mathrm{km}\end{array}$ & $\begin{array}{c}\lambda_{\mathrm{e} \min } \times 10^{3}, \\
1 / \mathrm{km}\end{array}$ & $\begin{array}{c}\lambda_{\mathrm{e}} \max \times 10^{3} \delta \\
1 / \mathrm{km}\end{array}$ \\
\hline 6,747 & 1,96 & 0,29 & 0,19 & 0,06 & 0,63 \\
\hline
\end{tabular}

Here $\lambda_{e}, \lambda_{\text {emin, }}, \lambda_{\text {emax }}$ are respectively average, minimum and maximum values of the parameter of operational disadvantages (intensity), and $\sigma_{\lambda \mathrm{e}}$ is its standard deviation.

According to the data of Table 2, it can be concluded that operational faults amount to 15 to $30 \%$ of the limit permissible level of structural and operational faults (1 fault per $1000 \mathrm{~km}$ ).

When using AWME for its intended purposes, there is an increase in the intensity of operational failures. The large discrepancy of $\lambda_{\mathrm{e}}$ values is explained by the variability of environmental conditions, different level of training of crews and maintenance personnel. In addition, it is worth noting the dispersion of the number of interruptions at the same values of the machine's mileage and the different consumption of motor life.

In general, we can assume that the operation of the barrel channel, armament, chassis, control system of the tank T-64B sample is not uniform and depends on a certain space of features that characterize the conditions of its tasks for intended purposes. Thus, the service life of the machine is most influenced by the operating conditions, in particular the motor oils quality and season suitability and the degree of training of the crew.

The connection between operating conditions, oil quality and a condition of the engine basic details is tendentiously seen [10]. It should be noted that the formal representation of the feature space is proposed by introducing a set of variables, different in their semantic load and dimension. For example, the operating conditions should take into account not only the time of year but also the nature of the tasks performed by the unit comprising the machine. In assessing the length of service, or "age" of the machine is appropriate to consider whether the machine has been overhauled, what is the direction after the last maintenance and predicted run of the technique to the next repair. Thus, the authors propose to define the range of features, which characterizes the conditions of the tank unit performing the tasks for the purpose, as follows:

$F_{1}$ - service life;

$\mathrm{F}_{2}$ - degree of crew training;

$\mathrm{F}_{3}$ - operation seasonality;

$\mathrm{F}_{4}$ - the nature of the tasks performed by the unit the sample belongs;

$\mathrm{F}_{5}$ - operating time of the machine after the last maintenance;

$\mathrm{F}_{6}$ - power reserve before the next repair.

In order to formalize the level of the crew training it is suggested to use the number of sample's failures of units and equipment occurred due to the fault of the crew and the repair units staff, which caused the fault during the operation or during maintenance and repair of the machine.

Thus, certain variables (predicates) have different dimensions, so to unify the processing of results, it is proposed to normalize the results of calculations. For predicates with an implicit dimension, it is proposed to use a peer expert assessment.

The processing of statistical data allows us to assume the normal character of the random variables that are chosen as predicates.

The use of the STATISTICA application package with sufficient and representative sampling allows to obtain weights for each variable. In the final form, the analytical relationship between the individual factors that determine the conditions of the sample T-64B tasks for its intended purpose, and the consumption of machine life as a dependent variable is proposed to be defined as a regression equation. Note that the feature space can be changed depending on the specific tasks.

2. Regression equation to obtain a unified analytical dependence of the influence of the conditions of the T-64B tank sample's tasks for the intended purposes on its service life. It is considered that the service life of the tank is the minimum allowable operating time of the machine before the next scheduled repair. It is assumed that the life between overhauls of the tank is the minimum allowable operating time of the machine up to the next scheduled repair, it is the duration or amount of time the machine is working, measured in $\mathrm{km}$ of run, engine hours, cycles, starts, shots [11].

In order to achieve unification in the calculation of the service life of the sample equipment, in particular, to take into account the random nature of the influence of the conditions of its tasks, operating time of separate knots and units and its accounting unit, it is proposed to put in accordance with the service life of the sample tank T-64B some numerical value $y$, which would characterize the dependence of the impact of the conditions of its tasks on the service life of the machine.

Let's define the dependence y on the values of the vector components $F=\left\{F_{1}, F_{2}, \ldots, F_{m}\right\}$ as a multiple linear regression as follows:

$$
y=a_{1} F_{1}+a_{2} F_{2}+\ldots+a_{m} F_{m},
$$

here $F=\left\{F_{i}\right\}$ - factors that determine the conditions of the T-64B sample tasks for the purpose; $\left\{a_{i}\right\}-$ regression coefficients to be determined.

It is natural to require a rationing condition in the form:

$$
\sum_{i=1}^{m}=1
$$

3 The least-squares method for regression coefficients renewal.

There are many ways of determining the coefficients of multiple regressions $[8,9]$. In this paper, the direct estimation of the set $\left\{a_{1}, a_{2}, \ldots, a_{m}\right\}, i=\overline{1, m}$, is proposed to be performed by the method of least squares. 
Suppose that, based on the results of processing statistical estimates of the service life of the tank T-64B samples, the accounting data for the number of failures and damage to systems for $n$ tanks, $j=\overline{1, n}$.. Assume that each $j$-th tank is subject to the same space of conditions $F_{i j}=\left\{F_{i l}, F_{i 2}, \ldots, F_{m}\right\}, j=\overline{1, n}, i=\overline{1, m}$.

Thus, to find the coefficients of the regression equation by the method of least squares, statistical data were obtained according to Table 3 .

\section{Table 3 - Service life of T-64B tank samples}

\begin{tabular}{|c|l|l|l|l|}
\hline $\begin{array}{c}\text { Number of failures } \\
\text { caused a decrease in } \\
\text { the tank service life }\end{array}$ & \multicolumn{4}{|c|}{$\begin{array}{c}\text { The value of the factors determine } \\
\text { the conditions of the T-64B tank } \\
\text { sample tasks for its intended } \\
\text { purpose }\end{array}$} \\
\hline$Y_{1}$ & $F_{11}$ & $F_{12}$ & $\ldots$ & $F_{1 m}$ \\
\hline$Y_{2}$ & $F_{21}$ & $F_{22}$ & $\ldots$ & $F_{2 m}$ \\
\hline$\ldots$ & $\ldots$ & $\ldots$ & $\ldots$ & $\ldots$ \\
\hline$Y_{n}$ & $F_{n 1}$ & $F_{n 2}$ & & $F_{n m}$ \\
\hline
\end{tabular}

It is proposed to calculate the coefficients of multiple linear regression in a matrix way. We present data and regression coefficients in matrix form

$$
A=\left[\begin{array}{c}
a_{1} \\
a_{2} \\
\ldots \\
a_{n}
\end{array}\right], Y=\left[\begin{array}{c}
y_{1} \\
y_{2} \\
\ldots \\
y_{n}
\end{array}\right], E=\left[\begin{array}{c}
e_{1} \\
e_{2} \\
\ldots \\
e_{n}
\end{array}\right], F=\left[\begin{array}{lll}
F_{11} & \ldots & F_{1 m} \\
F_{21} & \ldots & F_{2 m} \\
\ldots & \ldots & \ldots \\
F_{n 1} & \ldots & F_{n m}
\end{array}\right],
$$

here $Y$ - is a $n$-dimensional column of the independent variable; $F$ - matrix of $n \times m$ dimension values of conditions of the T-64B tank sample tasks of intended purposes; $A-$ is a n dimension vector-column of the coefficients of the regression equation; $E-$ is a $n$-dimension vector-column of deviations of the dependent variable $y_{i}$ from similar values obtained by the regression equation,

$$
\hat{y}_{i}=a_{i} F_{i 1}+a_{i} F_{i 2}+\ldots .+a_{i} F_{i n} .
$$

In matrix form, the relationship will look like:

$$
e=Y-F A \text {. }
$$

According to the least squares method

$$
\sum_{i=1}^{n} e_{i}^{2}=e^{T} e=(Y-F A)^{T}(Y-F A) \rightarrow \min
$$

It can be shown that the preceding condition is fulfilled if the vector column looks like

$$
A=\left(F^{T} F\right)^{-1} F^{T} Y \text {. }
$$

After the solution of equation (7) we obtain the value of coefficients of regression equation $A^{*}$. Therefore, the coefficients of the equation (3) are as follows:

$$
A=\left(A^{*}\right)^{T}
$$

Thus, the obtained values of the regression equation (2) and the known $F=\left\{F_{1}, F_{2}, \ldots, F_{m}\right\}$ can form the dependence of influence of operating conditions on the inter-maintenance resource of the machine $y$.
The unconditional advantage of this technique is that it makes it possible to conduct a comparative analysis of both existing and prospective samples of weapons with the desired conditions for the tasks assigned.

A definite advantage of this methodology is that it enables a comparative analysis of both existing and advanced AWME vehicles with the desired conditions for the purposes.

4.1 Proposals and engineering solutions for monitoring the parameters of individual component parts and systems of the tank during its life cycle. It is natural to believe that monitoring of technical condition of vehicles in military samples must be carried out consistently, regardless of their deployment (in places of permanent deployment or during military operations). It is the control of the parameters of individual assembly units and systems of the tank sample that plays a leading role in ensuring the combat readiness and efficiency of the use of aging samples of weapons, insures personnel against possible accidents and catastrophes, sudden failures. Given the results of the research, the authors propose to focus efforts on such engineering solutions [12-17].

4.2 Dipstick as a tool to improve technical diagnostics of the engine lubrication system. In order to prevent the causes of failure of the tank engine this work considers a proposal for improvement of the means of diagnostics and control of the technical condition of the engine lubrication system (LS) by carrying out maintenance according to its actual state.

Installation of the olive oil condition sensor is a reliable and cost-effective way to solve a number of problems of economic and ecological character. Sensors of this type perform complex monitoring of olive condition in real time, transmitting information to the electronic control unit (ECU) in real time mode.

The function of the engine oil sensor [18]: to accurately indicate the need to replace the olive; reduction of operating costs; minimization of machine downtimes; engine protection.

The olive oil sensor helps to protect the engine through early detection of failures in the engine system, the corresponding alarm signal to the driver and disable the possibility of starting the engine, if it can cause problems in the work of the engine. The optimum replacement time for the motor oil is determined with the utmost precision.

An example of implementation of physical and chemical method of diagnostics of motor oil quality can be a design of a dipstick. A distinctive feature of this development is a comprehensive analysis of the actual condition of the oil during operation of the machine, which is based on assessing the degree of its contamination, antifriction and anti-seizure properties, determining the level, temperature and viscosity of engine oil.

Fig. 1 shows a schematic diagram of a dipstick for motor oil quality control. The device is made in the form of a gauge and consists of sensors of the oil level, fouling, viscosity, load-bearing capacity and torque, temperature. All the sensors of the device are designed as independent modules located in a tube connected to the housing in 
which they are installed: The wrapping drive is connected to the sensors of tension, bearing capacity and torque; the information processing unit, which is connected to all the sensors and transmits information about the olive quality to the information panel [19].

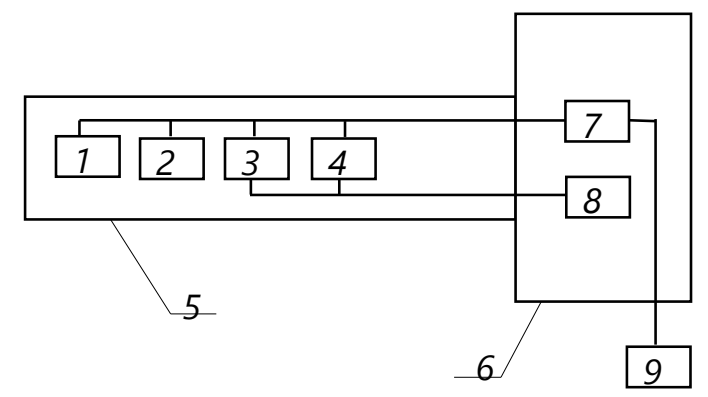

Fig. 1. Block diagram of the probe for oil quality control in the T-64B tank lubrication system: 1 - oil level sensor; 2 - pollution sensor; 3 - viscosity sensor; 4 - load-bearing capacity and torque sensor; 5 - tube; 6 - housing; 7 - stepper motor; 8 - information processing unit; 9 - information panel

In addition, the information processing unit provides the ability to select the oil quality control mode (continuous and periodic). For convenience of operation of the probe the information panel 9 on which the information on a condition of oil is displayed is provided. The information panel is made in a reliable case and can be placed in any convenient place in the control compartment. The design of the probe allows its installation and use on various types of weapons and military equipment. The principle of operation of the oil level sensor is that in the sections of the dipstick corresponding to the minimum and maximum oil level, an infrared emitter and a photodetector (photodiode) are built into the walls of the tank hull.

If the oil level does not reach the lower level of the sensor, the photodetector receives the signals of the emitter, which are reflected from the inner wall of the housing: the resistance of the diode decreases, as indicated by the corresponding LED on the display panel. At normal oil levels the boundary of the oil surface separates the receiver and the emitter. The purity sensor of motor oil is executed similarly to the optical level sensor, but in this case the radiator (lightemitting diode) and the receiver (photodiode) are directed opposite to each other. The signal received by the photodiode depends on the degree of transparency of the oil that is placed between the receiver and the emitter. The design of the viscosity sensor is based on the principle of a piston pump operation with an elastic membrane. As the piston moves down, the oil is partially expelled through the calibration holes, and the remaining part of the oil deforms the elastic membrane with the sensor. The lower of the oil viscosity, the more of it will pass from the cavity under the piston through the holes on the outside, and thus the deformation of the membrane will be less. At the critical (lower) viscosity level of the oil, the closing of the contact that is connected to the membrane will stop and the indication of the emergency state of the oil will turn on.

Friction force sensor (which characterizes the antifriction properties of the oil) and bearing capacity which is a miniature machine that is immersed in the oil under study. The friction unit in this sensor is formed by two spring electrodes, which are pressed against a metal cable with an elastic force, which is set so that under the action of the pressing force there is no rupture of the lubrication film in the new oil with acceptable antiemergency properties.

The rubbing force sensor (characterizes the antifriction properties of the olive) and load-bearing capacity which is a miniature machine which is immersed in the olive which is being inspected. The friction unit in this sensor is formed by two spring electrodes, which are pressed against a metal cable with an elastic force, which is set so that under the action of the clamping force there is no rupture of the lubricating film in the new oil with acceptable anti-seizure properties. During working off of anti-seizure additives in oil breaks of a film of greasing occur more often that will be displayed by burning of the corresponding LED.

As a drive for the diagnostic probe to ensure the operability of the modules for assessing the viscosity, antifriction and anti-seize qualities of the engine oil, an automated drive is proposed based on a stepper motor of the reciprocating motion of a flexible (steel) cable. The diagnostic probe monitors using five different sensors, which allows the need to replace the engine oil with high accuracy As a variant of the constructive basis of the diagnostic dipstick a capacitive fuel gauge sensor can be considered.

Note that it is the accounting of the engine will provide an opportunity to lead to a "single denominator" of its operation in hours and kilometers. Technical implementation of this idea is possible without making structural changes to the structure of the driver's panel.

\section{Conclusions}

The space of features characterizes the conditions of the tank sample tasks for its intended purposes, includes service life, crew training, operation, seasonality of the unit's performed tasks nature, machine operating time since the last service and range of the vehicle before the next overhaul.

The analytical relationship between the individual factors determining the conditions under which the $\mathrm{T}$ 64B tank sample performs its tasks for the intended purposes and the machine's service life consumption as a dependent variable can be determined in the form of a regression equation.

Differentiated control of the parameters of individual assembly units and systems of the tank sample plays a leading role in ensuring the combat readiness and efficiency of the use of aging samples of weapons, insures personnel against possible accidents and catastrophes, sudden failures.

\section{REFERENCES}

1. Chornyy, M.V., Dolhov, R.V. and Budyanu, R.H (2009), "On-Site Armament Maintenance and Repair and Military Equipment Strategies“, Viyskovo-tekhnichnyy zbirnyk Lvivskoho instytutu Sukhoputnykh viysk, vol. 1, pp. 65-68. 
2. Volokh, O.P. (2007), The technique of substantiation of rational values of the parameters of maintenance of machines of engineering armaments at their use on purpose, $\mathrm{Ph} . \mathrm{D}$. Thesis, Kamianets-Podilskyi, Ukraine

3. Lanetskiy, B.N., Luk'yanchuk, V.V. and Fomenko, D.V. (2009), "Justification of optimal maintenance and repair strategies for complex technical systems", Systemy obrobky informatsiyi, no. 6 (80), KhUPS, pp. 72-78.

4. Grib, D.A., Lanetskiy, B.N., Luk'yanchuk, V.V. and Mykhydenko, V.P. (2010), "Operation and repair of the technical condition of armaments and military equipment of anti-aircraft missile forces: problematic issues and ways to solve them", Systemy ozbroyennya i viys'kova tekhnika, no 4 (24), pp. 27-31.

5. Smironov, N.N. and Itskevich, A.A. (1987), On-Site maintenance and repair of aircraft, Transport, Moscow, SU.

6. Hulyayev, A.V., Zubaryev, O.V., Kanishchev, V.V. and Kolodyazhnyy, V.B. (2016), "Improving the efficiency of the system of maintenance and repair of weapons and military equipment", Ozbroyennya ta viys'kova tekhnika, no. 2(10), pp. 43-48.

7. Gusev, Yu.K. and Kritskiy, V.K (1979), "The influence of the ergonomic factor on operational failures", Voprosy oboronnoy tekhniki, no 84, vol. XX, available at: http://btvt.info/5library/vop_nadeznost_t_72_t_64.htm.

8. Goloshchapov, I.M. (1989), Ekspluatatsiya bronetankovogo vooruzheniya i tekhniki, Voyenizdat, Moscow, SU.

9. (1986), Obyekt 447A (437A). Tekhnicheskoye opisaniye $i$ instruktsiya po ekspluatatsii, Kniga 2, Voyennoye izdatelstvo Ministerstva oborony SSSR, Moscow, SU.

10. Krutilin, A.G. (2005), "Implementation of targeted programs for the development of systems for the operation, repair and storage of weapons and military equipment of state aviation", Voyennaya mysl, no. 8, pp. 15-17.

11. (1994), DSTU 2860-94. Reliability of equipment. Terms and definitions, State Standard of Ukraine, Kyiv, UA.

12. Zubarev, V.V., Kovtunenko, A.P. and, Raskyn, L.H. (2005), Mathematical methods for assessing and predicting technical indicators of the operational properties of radio-technical systems, NAU, Kyiv, UA.

13. Korn, G.A. and Korn T.M. (1973), Mathematical handbook, Nauka, Fizmatgiz, Moscow, SU.

14. Demydenko, E.Z. (1981), Lineynaya i nelineynaya regressiya, Finansy i statistika, Moscow, SU.

15. Buslenko, N.P. (1968), Modelirovaniye slozhnykh system, Nauka, Moscow, SU.

16. Makogon, Ye. A. amd Seraya, O.V. (2007), "Evaluation of the effectiveness of complex systems using the modified method of pairwise comparisons", Zbirnyk naukovykh prats' Kharkivs'koho universytetu Povitryanykh Syl, no. 3(15), pp. 112-116.

17. Venttsel, Ye.S. (1969), Teoriya veroyatnostey [Probability Theory], Nauka, Fizmatgiz, Moscow, SU.

18. (2020), SDU-1A-0.12 boundary support signaling device, available at: https://izi.ua/p-10794116-signalizatory-davleniyasdu1a-0-12-i-dr.

19. (2020), Microcontroller Arduino: characteristics, capabilities, available at: https://arduinoplus.ru/avtomatika-na-bazemikrokontrollera-arduino/.

Received (Надійшла) 21.06.2021

Accepted for publication (Прийнята до друку) 25.08.2021

\section{ABOUT THE AUTHORS / ВіДОМОСТІ ПРО АВТОРІВ}

Макогон Олена Анатоліївна - кандидат технічних наук, доцент кафедри бронетанкового озброєння та військової техніки, Військовий інститут танкових військ Національного технічного університету “ХПІ”, Харків, Україна;

Helen Makogon - Candidate of Technical Sciences, Associate Professor of the Armored vehicles and military equipment Department, Military Institute of Tank Troops of National Technical University “KhPI”, Kharkiv, Ukraine; e-mail: helmkg@ukr.net; ORCID: https://orcid.org/0000-0003-1112-8707.

Чалапко Володимир Вікторович - заступник начальника кафедри озброєння та стрільби, Військовий інститут танкових військ Національного технічного університету “ХПІ”, Харків, Україна.

Volodymyr Chalapko - Deputy Head the Department of Arms and Firing Department, Military Institute of Tank Troops of National Technical University "Kharkiv Polytechnic Institute", Kharkiv, Ukraine; e-mail: Chalapkovolodymyr@gmail.com; ORCID: https://orcid.orq/0000-0001-9833-9851.

Губа Сергій Михайлович - викладач кафедри підготовки офіцерів запасу, Військовий інститут танкових військ Національного технічного університету “ХПІ”, Харків, Україна;

Serhiy Guba - Lecture of the Reserve officers training department, Military Institute of Tank Troops of National Technical University "Kharkiv Polytechnic Institute", Kharkiv, Ukraine;

e-mail: gsm136bts@ukr.net; ORCID: https://orcid.org/0000-0002-2304-2321.

Стариченко Владислав Вікторович- магістрант кафедри бронетанкового озброєння та військової техніки, Військовий інститут танкових військ Національного технічного університету “ХПІ”, Харків, Україна;

Vladyslav Starychenko - Undergraduate Cadet of the Armored weapons and military equipment Department, Military Institute of Tank Troops of National Technical University "Kharkiv Polytechnic Institute”, Kharkiv, Ukraine; e-mail: vladyslavstarychenko@ukr.net ; ORCID: https://orcid.org/0000-0001-5940-4526.

Москаленко Віктор Іванович - доцент кафедри бронетанкового озброєння та військової техніки, Військовий інститут танкових військ Національного технічного університету “ХПІ”, Харків, Україна;

Viktor Moskalenko - Associate Professor of the Armored vehicles and military equipment Department, Military Institute of Tank Troops of National Technical University "Kharkiv Polytechnic Institute", Kharkiv, Ukraine; e-mail: kaf_ing_fvp@ukr.net; ORCID: https://orcid.org/0000-0002-4183-7953.

Красношапка Юрій Васильович - старший викладач кафедри озброєння та стрільби, Військовий інститут танкових військ Національного технічного університету “ХПІ”, Харків, Україна.

Yuriy Krasnoshapka- Senior Lecture of the Arms and Firing Department, Military Institute of Tank Troops of National Technical University "Kharkiv Polytechnic Institute", Kharkiv, Ukraine; e-mail: krasnoshapkayura@gmail.com; ORCID: https://orcid.org/0000-0001-9234-4844. 
Використання математичного апарату регресійного аналізу для уніфікації методики розрахунків міжремонтного ресурсу танка Т-64Б

О. А. Макогон, В. В. Чалапко, С. М. Губа, В. В. Стариченко, В. І. Москаленко, Ю. В. Красношапка

Анотація. Предметом вивчення в статті $є$ життєвий цикл зразка танка Т-64Б у період від нормальної експлуатації в навчально-бойовій групі до відпрацювання ресурсу і проведення середнього та капітального ремонту. Метою дослідження $є$ розроблення моделі залежності міжремонтного ресурсу зразка танка Т-64Б від умови експлуатації машини та на ії основі - методики контролю параметрів окремих складальних одиниць та систем зразка танка протягом його життєвого циклу. Завдання дослідження: проаналізувати результати статистичного обліку кількості відмов та пошкоджень систем танка та визначити множину предикат, які чинять вплив на міжремонтних ресурс машини в залежності від умов виконання нею завдань за призначенням; скласти рівняння регресії для отримання уніфікованої аналітичної залежності міжремонтного ресурсу зразка танка Т-64Б у період від нормальної експлуатації в навчально-бойовій групі до відпрацювання ресурсу і проведення середнього і капітального ремонту; дослідити питомий вплив надійнісних показників окремих складальних одиниць та систем на надійність зразка техніки та його міжремонтний ресурс; запропонувати інженерні рішення щодо реалізації методики контролю параметрів окремих складальних одиниць та систем зразка танка протягом його життєвого циклу. Методологічною основою дослідження стали загальнонаукові та спеціальні методи наукового пізнання. Отримані такі результати. Визначена множина предикат, які чинять вплив на міжремонтний ресурс машини в залежності від умов виконання нею завдань за призначенням; складено рівняння регресії для отримання уніфікованої аналітичної залежності міжремонтного ресурсу зразка танка Т-64Б у період від нормальної експлуатації в навчально-бойовій групі до відпрацювання ресурсу і проведення середнього і капітального ремонту; запропоновані інженерні рішення щодо реалізації методики контролю параметрів окремих складальних одиниць та систем зразка танка протягом його життєвого циклу, а саме: комплексний моніторинг стану оливи в реальному часі та облік мотогодин роботи двигуна при різних режимах навантаження. Висновки. Простір ознак, що характеризує умови виконання зразком танка завдань за призначенням, включає термін експлуатації, ступінь навченості екіпажу, сезонність експлуатації, характер завдань, що виконує підрозділ, до складу якого входить машина, напрацювання машини після останнього ТО та запас ходу машини до чергового ремонту. Аналітична залежність між окремими чинниками, що визначають умови виконання зразком танка Т-64Б завдань за призначенням та витрату експлуатаційного ресурсу машини як залежної змінної, може бути визначена у вигляді рівняння регресії. Диференційований контроль параметрів окремих складальних одиниць та систем зразка танка відіграє провідну роль у гарантуванні боєготовності та ефективності застосування старіючих зразків ОВТ, страхує особовий склад від можливих аварій і катастроф, раптових відмов.

Ключові слова: міжремонтний ресурс зразка танка Т-64Б; умови експлуатації; регресійний аналіз; диференційований контроль параметрів.

Использование математического аппарата регрессионного анализа для унификации методики расчетов межремонтного ресурса танка Т-64Б

Е. А. Макогон, В. В. Чалапко, С. М. Губа, В. В. Стариченко, В. И. Москаленко, Ю. В. Красношапка

Аннотация. Предметом изучения в статье является жизненный цикл образца танка Т-64Б в период от нормальной эксплуатации в учебно-боевой группе до выработки ресурса и проведения среднего и капитального ремонта. Целью исследования является разработка модели зависимости межремонтного ресурса образца танка Т-64Б от условия эксплуатации машины и на ее основе - методики контроля параметров отдельных сборочных единиц и систем образца танка в течение его жизненного цикла. Задачи исследования: проанализировать результаты статистического учета количества отказов и повреждений систем танка и определить множество предикат, которые оказывают влияние на межремонтных ресурс машины в зависимости от условий выполнения ею задач по назначению; составить уравнение регрессии для получения унифицированной аналитической зависимости межремонтного ресурса образца танка Т-64Б в период от нормальной эксплуатации в учебно-боевой группе к отработке ресурса и проведения среднего и капитального ремонта; исследовать удельное влияние надежностных показателей отдельных сборочных единиц и систем на надежность образца техники и его межремонтный ресурс; предложить инженерные решения по реализации методики контроля параметров отдельных сборочных единиц и систем образца танка в течение его жизненного цикла. Методологической основой исследования стали общенаучные и специальные методы научного познания. Получены следующие результаты. Определено множество предикат, которые оказывают влияние на межремонтный ресурс машины в зависимости от условий выполнения ею задач по назначению; составлено уравнения регрессии для получения унифицированной аналитической зависимости межремонтного ресурса образца танка Т-64Б в период от нормальной эксплуатации в учебно-боевой группе до выработки ресурса и проведения среднего и капитального ремонта; предложены инженерные решения по реализации методики контроля параметров отдельных сборочных единиц и систем образца танка в течение его жизненного цикла, а именно: комплексный мониторинг состояния масла в реальном времени и учет моточасов работы двигателя при различных режимах нагрузки. Выводы. Пространство признаков, характеризующих условия выполнения образцом танка задач по назначению, включает срок эксплуатации машины, степень обученности экипажа, сезонность эксплуатации, характер задач, выполняемых подразделением, в состав которого входит машина, наработки машины после последнего ТО и запас хода машины до очередного ремонта. Аналитическая зависимость между отдельными факторами, определяющими условия выполнения образцом танка Т-64Б задач по назначению и расход эксплуатационного ресурса машины как зависимой переменной, может быть определена в виде уравнения регрессии. Дифференцированный контроль параметров отдельных сборочных единиц и систем образца танка играет ведущую роль в обеспечении боеготовности и эффективности применения стареющих образцов ВВТ, страхует личный состав от возможных аварий и внезапных отказов.

Ключевые слова: межремонтный ресурс зразка танка Т-64Б; условия эксплуатации; регрессионный анализ; дифференцированный контроль параметров. 